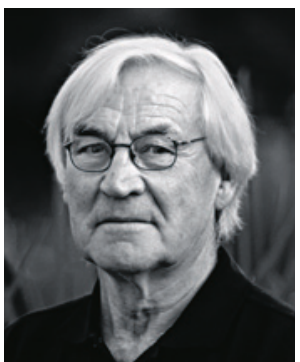

\title{
Mer lukkede helseinstitusjoner?
}

\section{Er helseinstitusjonene blitt mer lukket, og hvor objektive er lokal- avisene når sykehusstriden raser?}

Men først en historie fra den «gamle» verden, altså sånn midt i 1960-årene. Vi var gift og ventet vårt første barn. Riene var der, drosjen også, et kvarter senere sto vi i tett snødrev på trappa til Strinda sykehus, i dag asylmottak - for de fleste altså fortsatt en lukket institusjon.

Det var den også for undertegnede: For isvinden utenfor var liten mot den som åpnet seg da jeg som den vordende far også ville inn. Beskjeden var klar: - Nå kan De gå hjem. Nå har De gjort Deres. «Diset» til for første gang sto jeg alene tilbake på trappa.

Fem år senere ble vårt neste barn født på E.C. Dahls fødestiftelse, ledet av en vennlig overjordmor (het det visst). - Ville vi være med fødselen? «Vi» ville det. Det var kanskje følelsesmessig litt prematurt, for å si det med et aktuelt uttrykk. Men fremfor alt givende. Etterpå var det kaffe og rundstykker på sengekanten sammen med mor og nyfødt sønn.

Hva vil jeg med dette? Fortelle at spranget fra én fødselsinstitusjon - tilsynelatende unnfanget (!) under den spanske inkvisisjonen - til E.C Dahls «öppna landskap» fem år senere, neppe var en forvandling styrt av nye direktiver fra Sosialdepartementet og/eller Helsedirektoratet. Den gang som i dag var det høyst trolig ledelsens vilje til åpenhet det fremfor alt handlet om.

Vi skjønner alle sykehusenes krav til arbeidsro, konsentrasjon om det livreddende, og ikke minst taushetsplikten som må være absolutt, slik det også understrekes i pressens Vær varsom-plakat. Men må helseinstitusjonene også så ofte hvor behagelig det enn kan føles - stenge seg ute fra den mest rudimentære opplysningsplikten og overlate det til medierådgivere og/eller informasjonsavdelinger? For som oftest handler det ikke om pasientopplysninger i det hele tatt, men om $ø$ konomi, faglige vurderinger og politiske prioriteringer. I 1980-årene var forholdet mellom journalister og medierådgivere omtrent $1: 1$, senere har kommunikasjonsbransjen doblet seg. Hvor mange medierådgivere må det til for å skru i en lyspære, undret en gang en kjent kommentator. Den generelle helseopplysningen svekkes også av fagets ofte påfallende fravær.

Men pressen gjør av og til gruelige, uopprettelige feil. Jeg husker flyulykken i Torghatten i 1988. 36 mennesker omkom. Mange aviser gikk over stag under dekningen av begravelsene med nærbilder av mennesker i sorg. Det vakte sterk og forståelig kritikk over hele landet, men sterkest i nærdistriktet. Jeg glemmer ikke et møte med helse- og sykehuspersonalet i Brønnøysund der jeg som invitert PFU-leder fikk så hatten passet. Det tålte jeg utmerket. Viktigere var det som skjedde etterpå - at Pressens Faglige Utvalg vedtok en av flere tilleggsuttalelser til Vær varsom-plakaten. Den satte bom for den slags uetisk nærgåenhet, og er i det store og hele blitt respektert.

Norge har i sammenlikning med mange andre land sterke regionale medier, både aviser og lokalradio. Dette kan mest ses på som positivt. Gang på gang ser vi også at viktige spørsmål og debatter som berører hele landet, har sitt utspring i lokale og regionale medier. Men det har også en negativ side: Mediene blir - praktisk talt uten unntak - ensporede lobbyister for sitt eget spredningsområde. Analyser og et videre utsyn savnes. Opprop, protester og mer eller mindre skjellsord fra «mannen i gata» formidles ukritisk. Aviser og andre medier er blitt det beståendes beste venn når forandringer «rammer» distriktet.

Knapt noen politisk sak har skapt så mange følelser de senere årene som sykehusstriden mellom Molde og Kristiansund i den gamle «fogderistridens» fylke Møre og Romsdal. Det er ikke tvil om at journalistene «snek» seg over til heiagjengen, slik det også skjedde da Agderposten og Fedrelandsvennen tok parti i en tilsvarende strid på de kanter.

Men fogderistriden har også sine muntre sider. En gang i unge år jobbet jeg i Tidens Krav i Kristiansund. Vi samkjørte, som det heter, med da eksisterende Romsdal Folkeblad i Molde. Vi hadde forskjellige lokalsider, men felles første- og sisteside, en ustoppelig kilde til bråk og rasende telefoner fra Molde. En gang hadde det skjedd et drap i Kristiansund, en sjeldenhet i en hvilken som helst småby.

Straks var Molde-redaktøren på tråden, skummende av raseri. Min redaktør, en mild sørlending, lyttet tålmodig og lenge inntil han svarte: - Jeg vet ikke annet enn at du får skaffe deg ditt eget drap!

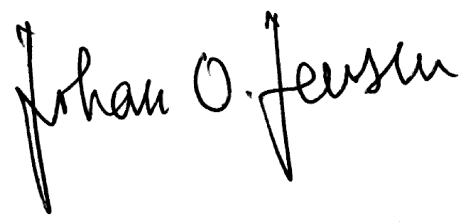

